\title{
RESPONSE OF THE NEUTRAL WIND TO INTENSE GEOMAGNETIC STORMS
}

Dyah R Martiningrum and Anwar Santoso

Space Science Center

Dr. Junjunan No. 133, Bandung, 40173

Telp : (022) 6012602, Fax : (022) 6014998

E-mail : dyah rm@bdg.lapan.go.id, dyahrm09@gmail.com

\begin{abstract}
ABSTRAK
Gangguan-gangguan yang terjadi di lapisan ionosfer berkaitan dengan badai geomagnet telah menjadi obyek penelitian yang menarik bagi para peneliti ionosfer selama beberapa dekade, dan oleh karena itu topik tersebut relatif telah banyak dipahami. Topik lain yang juga sedang dikaji adalah tentang pengaruh badai geomagnet terhadap parameter lapisan atmosfer. Mustel dkk, (1977) berdasarkan hasil penelitian mereka, menemukan adanya penurunan tekanan sesudah kejadian badai geomagnet sporadik yang kuat, sementara Pudovkin dan Veretenko (1992) mendapatkan adanya perubahan pada profil meridional dari tekanan atmosfer zonal selama badai geomagnet. Hasil penelitian terbaru oleh Gustavo A. Mansilla (2011) menyatakan bahwa parameter atmosfer seperti kecepatan angin dan temperatur dapat dipengaruhi oleh badai geomagnet. Dalam makalah ini, kami mengkaji kemungkinan adanya hubungan antara kecepatan angin netral dari Meteor Wind Radar Kototabang dan badai geomagnetik intensif yang terjadi dalam tahun 2003 dan 2004. Dengan memanfaatkan suatu metode statistik telah dibandingkan antara kecepatan angin netral saat badai dengan standar deviasinya yang diperoleh saat kondisi tenang (tidak terjadi badai geomagnet). Hasilnya menunjukkan bahwa badai geomagnet mempengaruhi kecepatan angin netral di atas Kototabang.
\end{abstract}

Kata Kunci : Kecepatan angin netral, badai geomagnet, Meteor Wind Radar

\begin{abstract}
Perturbations of the ionosphere related to geomagnetic storms have been an object of a close attention of ionospheric researchers for several decades and therefore are relatively well known. Effects of geomagnetic storms to atmospheric parameter have been studied. Mustel et al.,(1977) summarized a decrease of pressure after strong sporadic geomagnetic storms, while Pudovkin and Veretenko (1992) summarized changes of the meridional profile of the zonal atmospheric pressure during geomagnetic strom. Recently, Gustavo A. Mansilla (2011) obtain that atmospheric parameters such as wind speed and temperature could be affected by geomagnetic storms. In this paper we examine the possible connection between neutral wind speed from Meteor Wind Radar Kototabang and intense geomagnetic storms occured in 2003 and 2004. By statistical method we compare storm time value of neutral wind speed over Kototabang with their standard deviation obtained from quiet time value. The results shows that geomagnetic storms influence neutral wind speed over Kototabang.
\end{abstract}

Keywords : neutral wind speed, geomagnetic storms, Meteor Wind Radar.

\section{INTRODUCTION}

Ionospheric responses to changes in geomagnetic activity have been the subject of intensive study for many years. Progress and understanding on this topic explain that a large amount of energy deposited in the thermosphere at high latitude during geomagnetic disturbances 
such as geomagnetic storm, leads to increase of neutral gas temperature (T) and variations of neutral composition $\left([\mathrm{O}] /\left[\mathrm{N}_{2}\right]\right)$. Both these factors cause a decrease in maximum electron concentration of ionospheric $\mathrm{F}_{2}$ layer $\left(\mathrm{NmF}_{2}\right)$ at the high latitude ionosphere. A thermosphere circulation spreads the heated gas to lower latitude (Gordienko, et.al., 2011).

There is also some evidence, pointing to the geomagnetic storm forcing of the Earth's climate. Statistically significant correlation at $99 \%$ confidence level among geomagnetic activity and some climatic parameters, such as the sea level atmospheric pressure and surface air temperature have been found (Mufti and Shah, 2011).

In this paper we examine the possible connection between another climatic parameter such as neutral wind speed from Meteor Wind Radar Kototabang and intense geomagnetic storms occured in 2003 and 2004. It consider that geomagnetic storm affect to pressure, temperature, and neutral wind speed (Mustel, et.al., 1977 ; Veretenko, 1992 ; Gustavo A. Mansilla, 2011). By statistical method we compare storm time value of neutral wind velocity over Kototabang with their standard deviation obtained from quiet time value.

\section{DATA AND METHOD}

Response of the neutral wind speed to intense geomagnetic storms can be observed by determine relations and correlations between geomagnetic storm and neutral wind were explained by comparation between Dst index and neutral wind speed.

The three considered geomagnetic storms occured on 30 October 2003 (peak Dst $=-221$ nT) ; 8 November 2004 (peak Dst $=-213$ nT) and 10 November 2004 (peak Dst $=-190$ nT). By considering the index Dst we select the five quietest days of the month of the storm and calculate average values and standard deviation for the analyzed parameters separately for 00 and 12 UT because standard deviation is different for different UT. The five quietest days are needed to obtain the geomagnetic index Dst for storm days. The geomagnetic index Dst is used to represent the level of geomagnetic activity. The hourly values of Dst were obtained from the world Data Center at the University of Kyoto database (http://swdc.kugi.kyoto-u.ac.jp/dstdir).

The neutral wind data which appropriate to geomagnetic storms obtained from Meteor Wind Radar, Kototabang. We select the five quietest days of the month of the storm and calculate average value and standard deviation for the analyzed neutral wind separately for 00 and 12 UT of $80 \mathrm{~km}$ and $98 \mathrm{~km}$ height.

\section{RESULTS AND ANALYSIS}

The present study analyze 3 cases of geomagnetic storm occurances are 30 October 2003, 8 November 2004, and 10 November 2004. The first analysis related to geomagnetic storm 26 October 2003 - 3 November 2003. Figure 1 show Dst index related to geomagnetic storm occurance (1a) and wind velocity at $80 \mathrm{~km}(1 \mathrm{~b})$ and $98 \mathrm{~km}(1 \mathrm{~d})$.

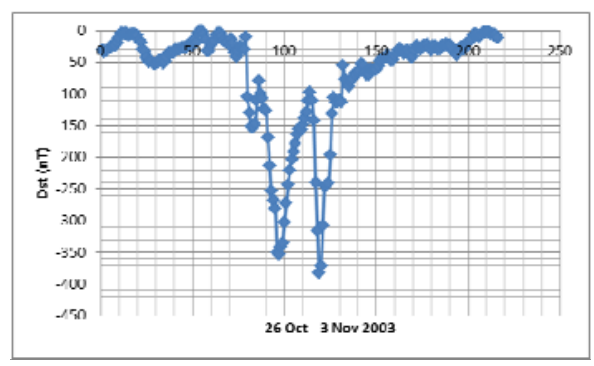

Figure (1a). Dst index related to geomagnetic storm occurance.

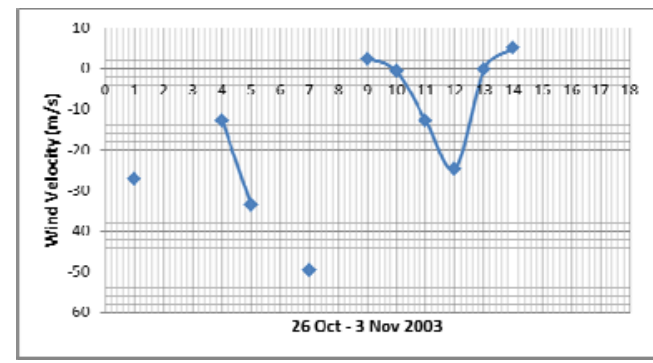

Figure (1b). The neutral wind velocity at $80 \mathrm{~km}$, picked for 00 and $12 \mathrm{UT}$ 
Figure (1a), (1b), and (1d) show that during geomagnetic storm events, wind speed data seems follow pattern of Dst index, mainly at peak of main phase. So, the data show possible influence of the geomagnetic storm or geomagnetic disturbance on mesospheric circulation. While figure (1c) and (1e) show spread out a distribution of data. It means that wind speed at $98 \mathrm{~km}$ more variable than wind speed at $80 \mathrm{~km}$.

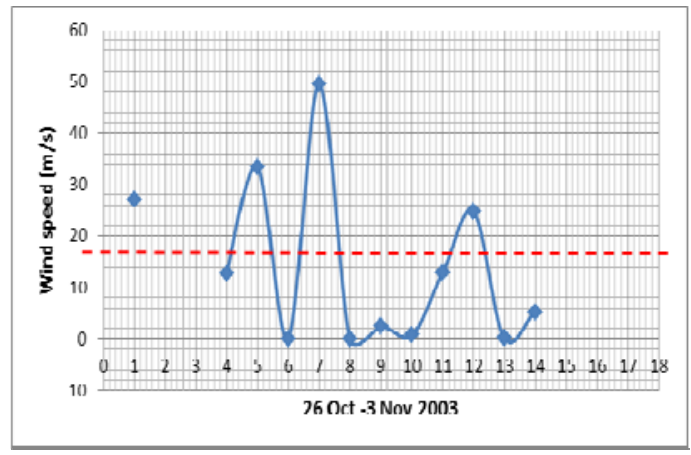

Figure (1c). The neutral wind speed at $80 \mathrm{~km}$, picked for 00 and 12 UT. Red dashes line indicate standard deviation.

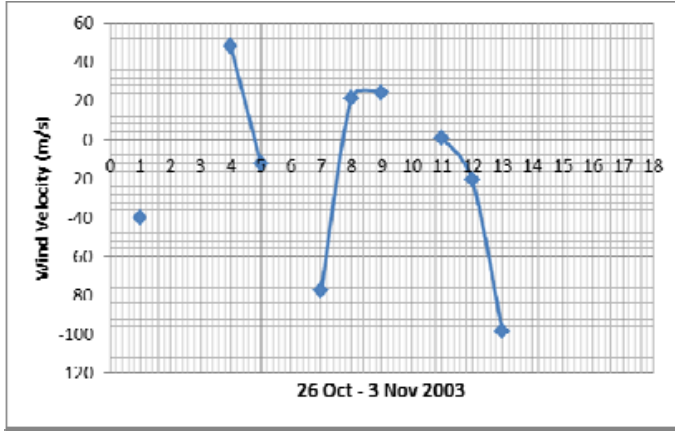

Figure (1d). The neutral wind velocity at $98 \mathrm{~km}$, picked for 00 and $12 \mathrm{UT}$

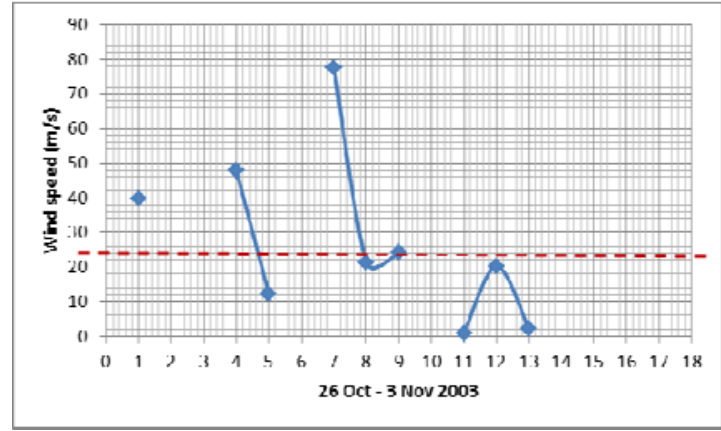

Figure (1e). The neutral wind speed at $98 \mathrm{~km}$, picked for 00 and 12 UT. Red dashes line indicate standard deviation

The second analysis related to geomagnetic storm 4-12 November 2004. Figure 2 show Dst index related to geomagnetic storm occurance (2a) and wind velocity at $80 \mathrm{~km} \mathrm{(2b)}$ and $98 \mathrm{~km}$ (2d). Similar to first case, in this second case wind velocity looks like follow decreasing of Dst

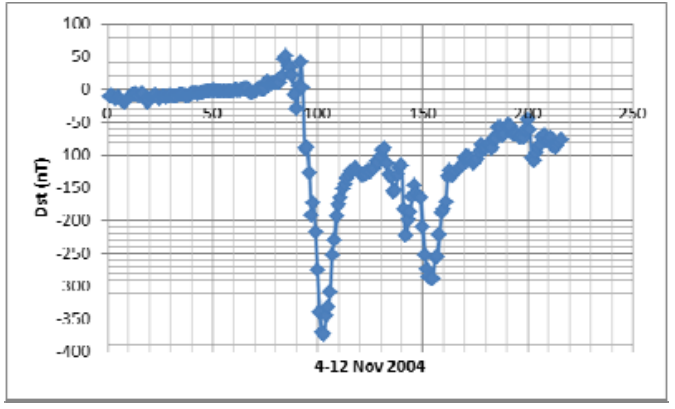

Figure (2a). Dst index related to geomagnetic storm occurance

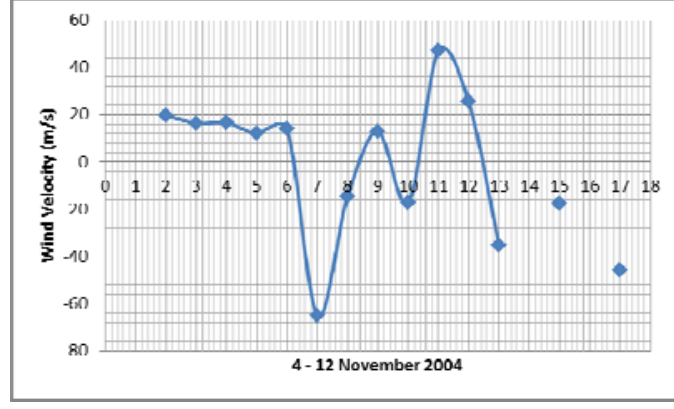

Figure (2b). The neutral wind velocity at $80 \mathrm{~km}$, picked for 00 and 12 UT 
index during storms. The results also show that wind speed at $98 \mathrm{~km}$ more variable than wind speed at $80 \mathrm{~km}$. It needed more data to confirm that variability of neutral wind speed as response to intense geomagnetic storms.

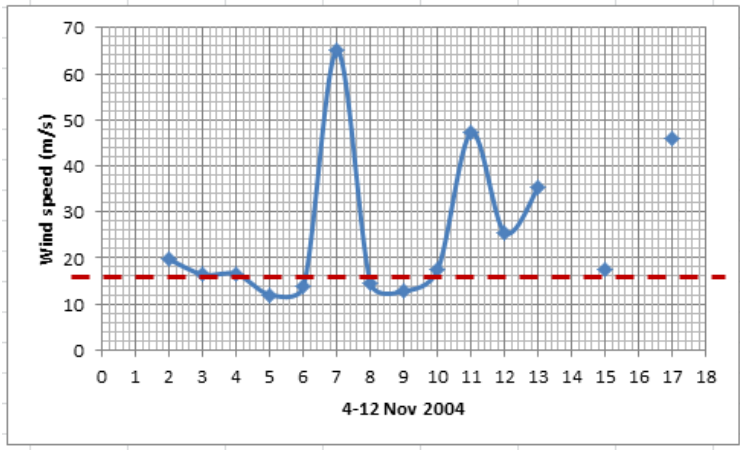

Figure (2c). The neutral wind speed at $80 \mathrm{~km}$, picked for 00 and $12 \mathrm{UT}$. Red dashes line indicate standard deviation.

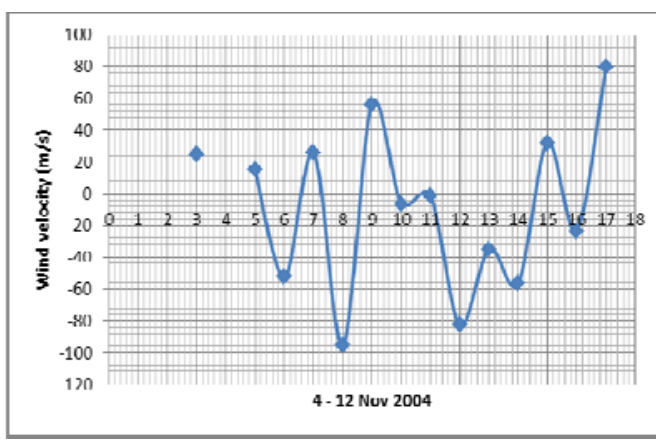

Figure (2d). The neutral wind velocity at $98 \mathrm{~km}$, picked for 00 and $12 \mathrm{UT}$

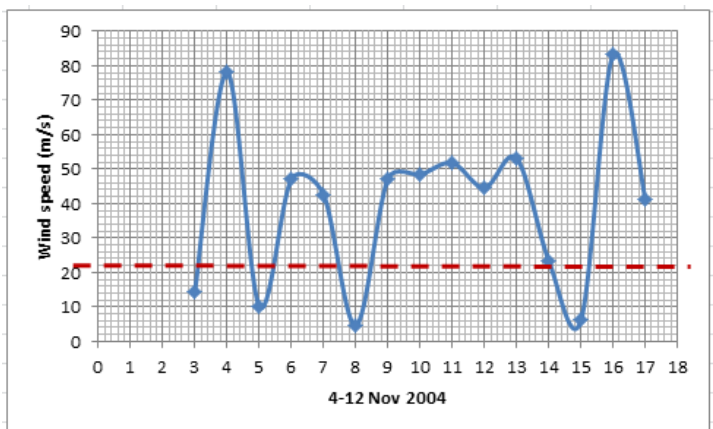

Figure (2e). The neutral wind speed at $98 \mathrm{~km}$, picked for 00 and $12 \mathrm{UT}$. Red dashes line indicate standard deviation.

Similar to the two previous case, figure (2a), (2b), and (2d) show that geomagnetic storm 8 and 10 November 2004 affect wind speed, mainly at main phase of storm as decrease of wind speed. So, this result is also support suggestion that geomagnetic storm or geomagnetic disturbance affect mesospheric circulation. Although there is some evidence of effects of geomagnetic storms, a mechanism able to explain the relations and correlations observed has not been established yet.

\section{CONCLUSION}

The relations and correlations between geomagnetic storm and neutral wind were observed by comparation between Dst index and neutral wind speed. By statistical method we compare storm time value of neutral wind speed over Kototabang. The results shows that geomagnetic storms influence neutral wind speed over Kototabang. The results support previous work have already done at another place, such as Argentina (Gustavo, 2011). Although there is some evidence of effects of geomagnetic storms, a mechanism able to explain the relations and correlations observed has not been established yet. 


\section{ACKNOWLEDGEMENT}

The authors would like to thank Mr. Syafrijon as Chairman of Kototabang Station which operated Meteor Wind Radar under collaboration with RISH, Kyoto University for providing data. The authors would also like to thank our colleagues Mr. Peberlin Sitompul and Mr. Mario Batubara for data sharing and discussion about Meteor Wind Radar.

\section{REFERENCES}

1. Gustavo, A.M. Response of the lower atmosphere to intense geomagnetic storms. Adv. in Space Reasearch. 48, 806-810, 2011.

2. Gordienko, G.I., Vodyannikov, V.V., Yakovets, A.F. Geomagnetic storm effects in the ionospheric E- and F-regions. Journal of Atmospheric and Solar Terrestrial Physics. 73, 18181830, 2011.

3. Mufti, S., Shah, G.N. Solar geomagnetic activity influence on Earth's climate. Journal of Atmospheric and Solar Terrestrial Physics, 73, 1607-1615, 2011.

4. Mustel, E.R., Chertoprud, V.E., Kovedeliani, V.A. Comparison of changes of the field of surface air pressure in the period of high and low geomagnetic activity. Astron. Zhurnal 54, 682-697, in Russian, 1977.

5. Pudovkin, M.I., Veretenko, S.V., Variations of meridional profile of atmospheric pressure during geomagnetic disturbances. Geomagn. Aeron. 32, 118-122, 1992. 